\title{
Hydrochar-Facilitated Anaerobic Digestion: Evidence for Direct Interspecies Electron Transfer Mediated through Surface Oxygen-Containing Functional Groups
}

Ren, Shuang; Usman, Muhammad; Tsang, Daniel C W; O-Thong, Sompong Angelidaki, Irini; Zhu, Xiangdong; Zhang, Shicheng; Luo, Gang

\section{Published in:}

Environmental Science and Technology

Link to article, DOI:

10.1021/acs.est.0c00112

Publication date:

2020

Document Version

Publisher's PDF, also known as Version of record

Link back to DTU Orbit

Citation (APA):

Ren, S., Usman, M., Tsang, D. C. W., O-Thong, S., Angelidaki, I., Zhu, X., Zhang, S., \& Luo, G. (2020). Hydrochar-Facilitated Anaerobic Digestion: Evidence for Direct Interspecies Electron Transfer Mediated through Surface Oxygen-Containing Functional Groups. Environmental Science and Technology, 54(9), 5755-5766. https://doi.org/10.1021/acs.est.0c00112

\section{General rights}

Copyright and moral rights for the publications made accessible in the public portal are retained by the authors and/or other copyright owners and it is a condition of accessing publications that users recognise and abide by the legal requirements associated with these rights.

- Users may download and print one copy of any publication from the public portal for the purpose of private study or research.

- You may not further distribute the material or use it for any profit-making activity or commercial gain

- You may freely distribute the URL identifying the publication in the public portal 


\title{
Hydrochar-Facilitated Anaerobic Digestion: Evidence for Direct Interspecies Electron Transfer Mediated through Surface Oxygen- Containing Functional Groups
}

\author{
Shuang Ren, Muhammad Usman, Daniel C. W. Tsang, Sompong O-Thong, Irini Angelidaki, \\ Xiangdong Zhu, Shicheng Zhang, and Gang Luo*
}

Cite This: Environ. Sci. Technol. 2020, 54, 5755-5766

Read Online

ACCESS | Lلll Metrics \& More | 回 Article Recommendations | st Supporting Information

ABSTRACT: Acceleration of the anaerobic digestion (AD) process is crucial to achieving energy-efficient recycling of organic wastes. Hydrochar is produced by hydrothermal liquefaction of biomass, yet its application in the $\mathrm{AD}$ process is rarely reported. The present study showed that sewage sludge-derived hydrochar $(\mathrm{SH})$ enhanced the methane production rate of glucose by $37 \%$. SH increased the methane production rate from acetate but did not affect acidification and the methane production rate from $\mathrm{H}_{2} / \mathrm{CO}_{2}$. $\mathrm{SH}$ enhanced hydrogenotrophic methanogenesis, which could be due to direct interspecies electron transfer (DIET) by converting $\mathrm{H}^{+}, \mathrm{e}^{-}$, and $\mathrm{CO}_{2}$ to methane. Trichococcus and Methanosaeta were dominant in the $\mathrm{AD}$ process with SH. Label-free proteomic analysis showed Methanosaeta was involved in DIET as reflected by the up-regulation of proteins involved in hydrogenotrophic methanogenesis. Hydrochars derived from corn straw $(\mathrm{CH})$, Enteromorpha algae $(\mathrm{EH})$, and poplar wood $(\mathrm{PH})$, as well as activated carbon $(\mathrm{AC})$, were also tested in the $\mathrm{AD}$ process. $\mathrm{SH}, \mathrm{CH}$, and $\mathrm{EH}$ obviously increased the methane production rates, which were $39 \%, 15 \%$, and $20 \%$ higher than the control experiment, respectively. It was neither electrical conductivity nor the total redox property of hydrochars and $\mathrm{AC}$ but the abundances of surface oxygen-containing functional groups that correlated to the methane production rates.

\section{INTRODUCTION}

Anaerobic digestion $(\mathrm{AD})$ is an efficient process for mitigation of a broad variety of waste biomass and production of methane at the same time. ${ }^{1}$ However, the unstable performance of the $\mathrm{AD}$ process due to the fluctuation of characteristics and flow rates of feedstocks is a major issue, which could lead to volatile fatty acid (VFA) accumulation. ${ }^{2}$ The accumulation of large amounts of VFA would result in the failure of the $\mathrm{AD}$ process. ${ }^{3}$ Efficient conversion of VFA (e.g., propionate, butyrate, and ethanol) to methane requires syntrophic interaction of VFA oxidizing bacteria and hydrogenotrophic methanogens, which could assist in maintaining a low $\mathrm{H}_{2}$ concentration-an interrelation commonly described as interspecies hydrogen transfer (IHT). ${ }^{4}$

Considerable efforts have been made to accelerate the methane production rates. ${ }^{5,6}$ It has been shown that conductive materials such as activated carbon (AC) and magnetite could improve the methane production rate of VFA and thereby increase the $\mathrm{AD}$ efficiency. Most previous studies suggested that the conductive materials could facilitate direct interspecies electron transfer (DIET) in the $\mathrm{AD}$ process. DIET is a syntrophic metabolism, and the electrons directly flow from exoelectrogenic bacteria to electrotrophic methanogen through cell components (cytochrome $\mathrm{C}$ and pilin) or conductive materials without the formation of $\mathrm{H}_{2}$, which is a more effective method for VFA degradation compared to IHT. $^{8}$ The genus Geobacter was the only genus that was demonstrated to achieve DIET until 2018, and only one bacterium (Syntrophus aciditrophicus) besides the genus Geobacter was recently demonstrated to participate in DIET. ${ }^{9}$ However, the enrichment of the above bacteria was not found in most previous studies with the addition of conductive materials in the $\mathrm{AD}$ process. ${ }^{4,8,10}$ The mechanism is still not clear, since $\mathrm{AD}$ is a very complex process and involves many different microbes. In addition, researchers are also trying to explore low-cost conductive materials to accelerate the methane production rate. For instance, biochar, which is

Received: January 7, 2020

Revised: March 26, 2020

Accepted: April 7, 2020

Published: April 7, 2020

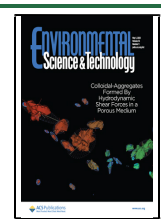



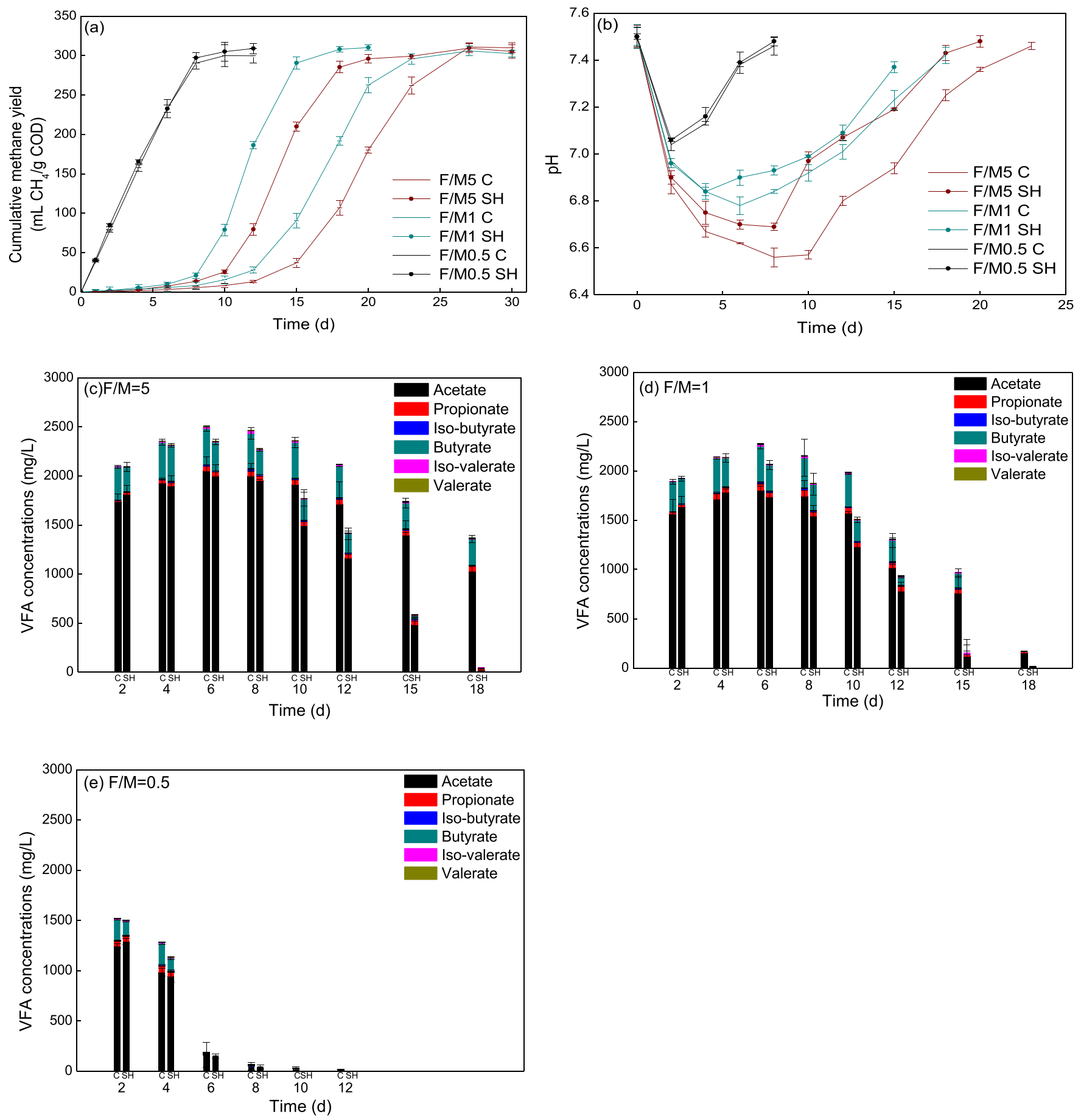

Figure 1. Effects of $\mathrm{SH}$ on methane production at different $\mathrm{F} / \mathrm{M}$ ratios: (a) cumulative methane yield at $\mathrm{F} / \mathrm{M}$ of $0.5,1$, and 5; (b) pH variation at different $\mathrm{F} / \mathrm{M}$ ratios; VFA concentrations variation at (c) $\mathrm{F} / \mathrm{M}=5$, (d) $\mathrm{F} / \mathrm{M}=1$, (e) $\mathrm{F} / \mathrm{M}=0.5$.

produced by pyrolysis of biomass, has been shown to raise the methane production rate. 8,11

Hydrothermal liquefaction (HTL) of biomass (sewage sludge, corn straw, etc.) is a thermochemical process that converts biomass into liquid and solid fuels by processing in hot and pressurized water environment $\left(200-350{ }^{\circ} \mathrm{C}\right.$ and $4-$ $22 \mathrm{MPa}$ ) for certain time to degrade the solid biopolymeric structures, and this process is more suitable for the treatment of wet biomass compared to pyrolysis. ${ }^{12,13}$ Hydrochar is the solid product from the HTL process, and it has better performances compared to the raw biomass in terms of higher mass and energy density, better dewaterability, and improved combustion performance as a solid fuel. ${ }^{14}$ In addition, hydrochar can also be applied as soil amendments. ${ }^{15}$ Compared to biochar, the application of hydrochar for the enhancement of methane production has been sparsely reported. ${ }^{7}$ A recent study showed that the addition of hydrochar to the $\mathrm{AD}$ process treating dead pig carcasses increased the methane yield and also methane production rate, which was mainly attributed to the decrease of free ammonia concentration due to the adsorption of ammonia by hydrochar and the slightly decreased $\mathrm{pH}^{16}$ However, a detailed 
mechanism is still unknown, especially from the microbial aspects. Although there is still no literature reporting the conductivity of hydrochar, it is known that hydrochar has redox-active properties. ${ }^{17}$ Previous studies showed that biochar could facilitate DIET for microbial reduction of ferrihydrite and methanogenesis due to its redox-active properties. ${ }^{18,19}$ Therefore, it was hypothesized that hydrochar could promote methanogenesis through DIET. Previous studies also showed the characteristics of hydrochar (e.g., redox properties) varied with the types of feedstocks, and it might have different effects on $\mathrm{AD}$, which remains to be elucidated. ${ }^{15,20}$ In addition, the commonly used high-throughput sequencing of $16 \mathrm{~S}$ rRNA genes analysis could only provide information on microbial community compositions but could not provide insights into the reactions taking place in the $\mathrm{AD}$ process. It is crucial to reveal the changes of metabolic pathways with the addition of hydrochar to better understand the real functions of hydrochar in the $\mathrm{AD}$ process. The proteomic analysis could reveal the changes of enzymes involved in different reactions and thereby provide important metabolic information on the microbial communities. ${ }^{4,21}$ The combination of $16 \mathrm{~S}$ rRNA genes and proteomic analysis could reveal the microbial mechanism of the $\mathrm{AD}$ process with the addition of hydrochar.

On the basis of the above considerations, the present study aimed to investigate the possibility of using hydrochar derived from sewage sludge to enhance the methane production rate from the model compound glucose, and the microbial mechanism was investigated by stable carbon isotope analysis, high-throughput sequencing of 16S rRNA genes analysis, and label-free proteomic analysis. In addition, the commonly used activated carbon (AC) and hydrochars derived from different feedstocks were used as a comparison to identify the main characteristics of hydrochar contributing to the promotion of methane production rate.

\section{MATERIALS AND METHODS}

Preparation of Hydrochar. Hydrochar was obtained by HTL of dewatered sewage sludge $(\mathrm{SH})$, which was obtained from a wastewater treatment plant in Shanghai, China. HTL was conducted in a $3 \mathrm{~L}$ hydrothermal reactor at $300{ }^{\circ} \mathrm{C}$ for $1 \mathrm{~h}$, which was a common operation set up for bio-oil production. ${ }^{12}$ The detailed information about the operation of the HTL process was described in our previous study. ${ }^{13}$ The bio-oil attached on hydrochar was removed by washing with tetrahydrofuran (THF). Hydrochar was soaked in THF (10 $\mathrm{mL} \mathrm{THF/g} \mathrm{hydrochar),} \mathrm{and} \mathrm{the} \mathrm{mixture} \mathrm{was} \mathrm{shaken} \mathrm{for} 1 \mathrm{~h}$ in a shaker at ambient temperature. THF was then removed by centrifugation. This process was repeated several times until THF after centrifugation became transparent, which indicated most bio-oil was removed. The hydrochar was then dried at 60 ${ }^{\circ} \mathrm{C}$ for $24 \mathrm{~h}$ for further utilization. In addition, corn straw, Enteromorpha algae, and poplar wood were used to prepare three additional hydrochars $(\mathrm{CH}, \mathrm{EH}$, and $\mathrm{PH}$, respectively) in order to make a comparison with SH. Activated carbon (AC) purchased from a commercial source was also used as a comparison. All the hydrochars and AC were ground and passed through a $2 \mathrm{~mm}$ sieve before usage. The characteristics of hydrochars and AC are summarized in Table S1.

Substrate and Inoculum. The inoculum was obtained from a mesophilic upflow anaerobic sludge blanket (UASB) reactor treating cassava stillage in an ethanol plant. The inoculum was put into a grinder (QX-650, Qinxin, China) and milled for $5 \mathrm{~min}$ to make it homogeneous before usage. The characteristics of the inoculum were as follows: total solids (TS) $37.2 \pm 2.8 \mathrm{~g} / \mathrm{L}$, volatile solids (VS) $30.1 \pm 1.9 \mathrm{~g} / \mathrm{L}$, and $\mathrm{pH} 7.21 \pm 0.08$. Glucose was used as a substrate.

Effects of SH on the Methane Production. The effects of $\mathrm{SH}$ on the methane production were investigated in batch experiments. The experiments were conducted in $118 \mathrm{~mL}$ serum bottles with a working volume of $60 \mathrm{~mL}$. Each bottle contained glucose $(4 \mathrm{~g} / \mathrm{L})$, sodium bicarbonate $(2 \mathrm{~g} / \mathrm{L})$, and BA medium. The composition of BA medium was described in a previous study. ${ }^{22}$ The bottles were inoculated with different amounts of inoculum to achieve glucose to inoculum mass ratios $(\mathrm{F} / \mathrm{M})$ of $0.5,1$, and 5 , which resulted in different initial organic loading rates. $\mathrm{SH}$ was added to the bottles to a final concentration $10 \mathrm{~g} / \mathrm{L}$, and the bottles without $\mathrm{SH}$ were used as a control. The bottles with only inoculum were used as a blank. In addition, the bottles without glucose but with $\mathrm{SH}$ were included to determine potential methane production from $\mathrm{SH}$ itself. The initial $\mathrm{pH}$ of each bottle was adjusted to 7.5. Bottles were flushed with pure $\mathrm{N}_{2}$ for $5 \mathrm{~min}$, sealed with butyl rubber stoppers, and then incubated at $37{ }^{\circ} \mathrm{C}$. The gas and liquid samples were collected every 2 days initially for analysis (Figure 1). The liquid samples were taken from the bottles with a syringe without opening the bottles. In order to understand the effects of hydrochar concentrations on methane production, additional experiments were conducted with hydrochar concentrations of $1 \mathrm{~g} / \mathrm{L}, 2.5 \mathrm{~g} / \mathrm{L}, 5 \mathrm{~g} / \mathrm{L}, 10 \mathrm{~g} /$ $\mathrm{L}, 15 \mathrm{~g} / \mathrm{L}$, and $20 \mathrm{~g} / \mathrm{L}$ with F/M 5 . All the tests were prepared in triplicate.

On the basis of the results from the above experiments, the bottles with F/M 5 and $10 \mathrm{~g} / \mathrm{L}$ hydrochar were further used for the second batch cultivation. The previous experiments also showed that there was a significant change of $\mathrm{pH}$ (between 6.6 and 7.5) during the batch experiments for methane production, and the bottles with $\mathrm{SH}$ generally had higher $\mathrm{pH}$ compared to the control. Therefore, the second batch experiments were conducted in two groups with uncontrolled $\mathrm{pH}$ and controlled $\mathrm{pH}$ at 7.5 by adding $2 \mathrm{M} \mathrm{NaOH}$ periodically. For the monitoring of $\mathrm{pH}$ in the bottles, liquid samples were taken from the bottles with a syringe without opening the bottles and then measured by $\mathrm{pH}$ meter daily. For the controlling of $\mathrm{pH}$, the bottles were opened, and then $2 \mathrm{M}$ $\mathrm{NaOH}$ was added to achieve the set value. After that, the bottles were purged with $\mathrm{N}_{2}$ gas for further incubation. The aim was to elucidate whether $\mathrm{SH}$ enhanced methane production by affecting $\mathrm{pH}$. The solid fraction from each bottle of the first experiments at F/M 5 with and without $\mathrm{SH}$ was separated by centrifugation and supplemented with fresh medium to a volume of $60 \mathrm{~mL}$, as previously mentioned. The mixture was then distributed equally to two $118 \mathrm{~mL}$ bottles, i.e., a $30 \mathrm{~mL}$ mixture in each bottle. One of the bottles was used in $\mathrm{pH}$-controlled experiments, and the other one was used in $\mathrm{pH}$ uncontrolled experiments. A modified Gompertz model was used to obtain the parameters including the maximum methane potential $(P)$, the maximum methane production rate $\left(R_{\mathrm{m}}\right)$, and lag phase $(\lambda)$ under different conditions (Supporting Information).

The effects of $\mathrm{SH}$ on the acidification of glucose were also determined. A $5 \mathrm{~mL}$ mixture of each bottle from the second experiment without $\mathrm{pH}$ control was added as inoculum in 118 $\mathrm{mL}$ bottles. Subsequently, $60 \mathrm{~mL}$ of BA medium and $\mathrm{SH}(10$ $\mathrm{g} / \mathrm{L}$ ) was added. Finally, the bottles were amended with glucose $(4 \mathrm{~g} / \mathrm{L})$ as a substrate, and bromoethanesulfonic acid (BES; $50 \mathrm{mM})$ was added as a specific methanogen inhibitor. 
The concentrations of VFA were then measured and analyzed periodically. The effects of $\mathrm{SH}$ on the methanogenesis were also determined. A similar procedure to the last experiments was adopted. However, BES was not added, and either acetate $(30 \mathrm{mM})$ or $\mathrm{H}_{2} / \mathrm{CO}_{2}(80: 20,1 \mathrm{~atm})$ was used as a substrate instead of glucose. All the tests were conducted in triplicate.

Stable carbon isotope analysis was conducted to investigate the methanogenic pathway with and without hydrochar in the second batch cultivation without a $\mathrm{pH}$ control, and the biogas was collected periodically for stable carbon isotope analysis. ${ }^{23}$ Carbon isotope fractionation $\left(\alpha_{c}\right)$ was calculated to characterize the changes of the methanogenesis pathway. Detailed information is described in the Supporting Information.

Effects of $\mathrm{SH}$ on the Microbial and Proteomic Patterns. The enriched mixed cultures in the second batch cultivation with F/M 5 and without $\mathrm{pH}$ control as described previously were collected from the bottles. Duplicate samples were retrieved randomly from the triplicate bottles when the methane production was close to half of the maximum value (i.e., around $150 \mathrm{~mL}$ of $\mathrm{CH}_{4} / \mathrm{g}$ of $\mathrm{COD}$ ), which corresponded to vigorous microbial metabolisms. $\mathrm{C} 1$ and $\mathrm{C} 2$ were obtained from the control bottles (without hydrochar), and $\mathrm{H} 1$ and $\mathrm{H} 2$ were obtained from the bottles with hydrochar. The taxonomic classification of all the sequences was first analyzed based on the high-throughput sequencing of 16S rRNA genes. DNA was extracted from each sample with the QIAamp DNA Stool Mini Kit (51504, QIAGEN) followed by polymerase chain reaction (PCR) amplification with primers 515F/806R. PCR products were then purified, quantified, and sequenced by Illumina Miseq platform. The sequences were submitted to NCBI with the accession number SUB5724470. More detailed information relating to PCR procedure and bioinformatics analysis is described in the Supporting Information.

The above microbial samples were also used for proteomic analysis. Total proteins were extracted by the phenol extraction method, and the extracted protein was enzymatically hydrolyzed by trypsin. The peptides were quantified and then analyzed by liquid chromatography coupled with tandem mass spectrometry (LC-MS/MS; Easy-nLC II nano liquid chromatograph, Thermo, USA; Q-Exactive mass spectrometer, Thermo, USA). Detailed information relating to protein preparation, mass spectrometry analysis, and data analysis is described in the Supporting Information.

Total bacteria, archaea, Methanobacteriales (MBT), Methanomicrobiales (MMB), Methanosarcina (MSC), and Methanosaeta (MST) in the samples were also quantified by qPCR with the corresponding primers (Supporting Information).

Effects of Hydrochars Derived from Different Feedstocks and $A C$ on Methane Production. The effects of hydrochars derived from different feedstocks and AC on methane production were also investigated, and the same procedure was adopted for the methane production experiments as previously described for methane production with $\mathrm{SH}$. The bottles without glucose but with different hydrochars and $\mathrm{AC}$ were also set up to determine the possibility of methane production from hydrochars and AC.

Analytical Methods. The analysis of methane content, VFA concentrations, and characteristics of hydrochars and AC is described in the Supporting Information. The analysis of variance (ANOVA) was used to test the significance of results, and $p<0.05$ was considered to be statistically significant.

\section{RESULTS AND DISCUSSION}

Effects of SH on Methane Production. The methane production at different $\mathrm{F} / \mathrm{M}$ ratios is shown in Figure 1a, and the kinetic parameters of methane production are summarized in Table S2. It should be noted that there was no methane production from $\mathrm{SH}$ itself. It was obvious that there were no significant differences in the methane production at $\mathrm{F} / \mathrm{M} 0.5$ with and without $\mathrm{SH}(p>0.05)$, while the reduced length of the lag phase and the increased methane production rate were observed at F/M 1 and 5 with $\mathrm{SH}$. For instance, $\mathrm{SH}$ resulted in a significant increase of $R_{\mathrm{m}}$ by about 33\% $(p<0.05)$ and $35 \%$ $(p<0.05)$ at $\mathrm{F} / \mathrm{M} 1$ and 5 compared to control without $\mathrm{SH}$, respectively. The $\mathrm{pH}$ varied between 6.5 and 7.5 during the whole periods (Figure $1 \mathrm{~b}$ ). The produced VFAs were mainly acetate and butyrate. The higher methane production rates with the presence of $\mathrm{SH}$ at $\mathrm{F} / \mathrm{M} 1$ and 5 were also correlated to the fast consumption of produced VFA as shown in Figure 1c and $\mathrm{d}$. For F/M 0.5, the presence of abundant bacteria and archaea in the bottles might result in the fast consumption of glucose and its intermediates, and therefore no differences were observed with and without $\mathrm{SH}$. The above results clearly showed that $\mathrm{SH}$ enhanced the methane production rate at high F/M. Further experiments also showed that $10 \mathrm{~g} / \mathrm{L} \mathrm{SH}$ was optimal for the enhancement of the methane production rate (Figure S1 and Table S3). The hydrochar concentration (10 $\mathrm{g} / \mathrm{L}$ ) used in the present study was in the range of previously reported concentrations $(0.5-50 \mathrm{~g} / \mathrm{L})$ of different materials (e.g., magnetite, GAC, biochar, carbon nanotube, etc.) to enhance the $\mathrm{AD}$ process. ${ }^{7,8}$

A second batch cultivation was further conducted at F/M 5 without $\mathrm{pH}$ control (Figure S2 and Table S2). The lag phase was decreased, and $R_{\mathrm{m}}$ was increased with and without $\mathrm{SH}$ compared to those of the first batch experiment, indicating the acclimatization of the mixed culture. $R_{\mathrm{m}}$ in the presence of $\mathrm{SH}$ was significantly increased by $37 \%(p<0.05)$ in the second batch, which showed the stable promotion effects of $\mathrm{SH}$ on the methane production rate. The higher consumption of produced VFA and faster recovery of $\mathrm{pH}$ were also observed in the presence of $\mathrm{SH}$. It should be noted that $\mathrm{pH}$ at $\mathrm{F} / \mathrm{M} 5$ was significantly decreased to 6.6 due to the production of VFA on day 8 . It was known that acidic $\mathrm{pH}$ had inhibition on methanogens. ${ }^{24}$ Therefore, an experiment with a constant $\mathrm{pH}$ at 7.5 was also conducted in order to see whether $\mathrm{SH}$ could still promote methane production at the optimal $\mathrm{pH}$ for methane at F/M 5. The results showed that with controlled $\mathrm{pH}$, the lag phases were decreased, and the $R_{\mathrm{m}}$ in the presence of SH was significantly increased by $27 \%(p<0.05$; Table S2 and Figure S3). The shorter lag phase than in the uncontrolled $\mathrm{pH}$ experiment could be due to the fast adaption of methanogens at the optimal $\mathrm{pH}$. For the reactors operated at optimal $\mathrm{pH}$ but with high $\mathrm{F} / \mathrm{M}, \mathrm{SH}$ still could promote the methane production rate. However, the increase of $R_{\mathrm{m}}(27 \%)$ by $\mathrm{SH}$ in a $\mathrm{pH}$ controlled experiment was lower than that in a $\mathrm{pH}$ uncontrolled experiment (37\%), which indicated that $\mathrm{SH}$ could more efficiently promote methane production at inhibited conditions (e.g., low $\mathrm{pH}$ ). A previous study showed hydrochar could alleviate ammonia inhibition, ${ }^{16}$ which was not the case in the present study where no ammonia inhibition was present. Therefore, further studies were conducted to reveal the role of $\mathrm{SH}$ in the $\mathrm{AD}$ process.

Effects of SH on the Individual Steps in AD Process. In order to understand how $\mathrm{SH}$ affected the $\mathrm{AD}$ process, the 

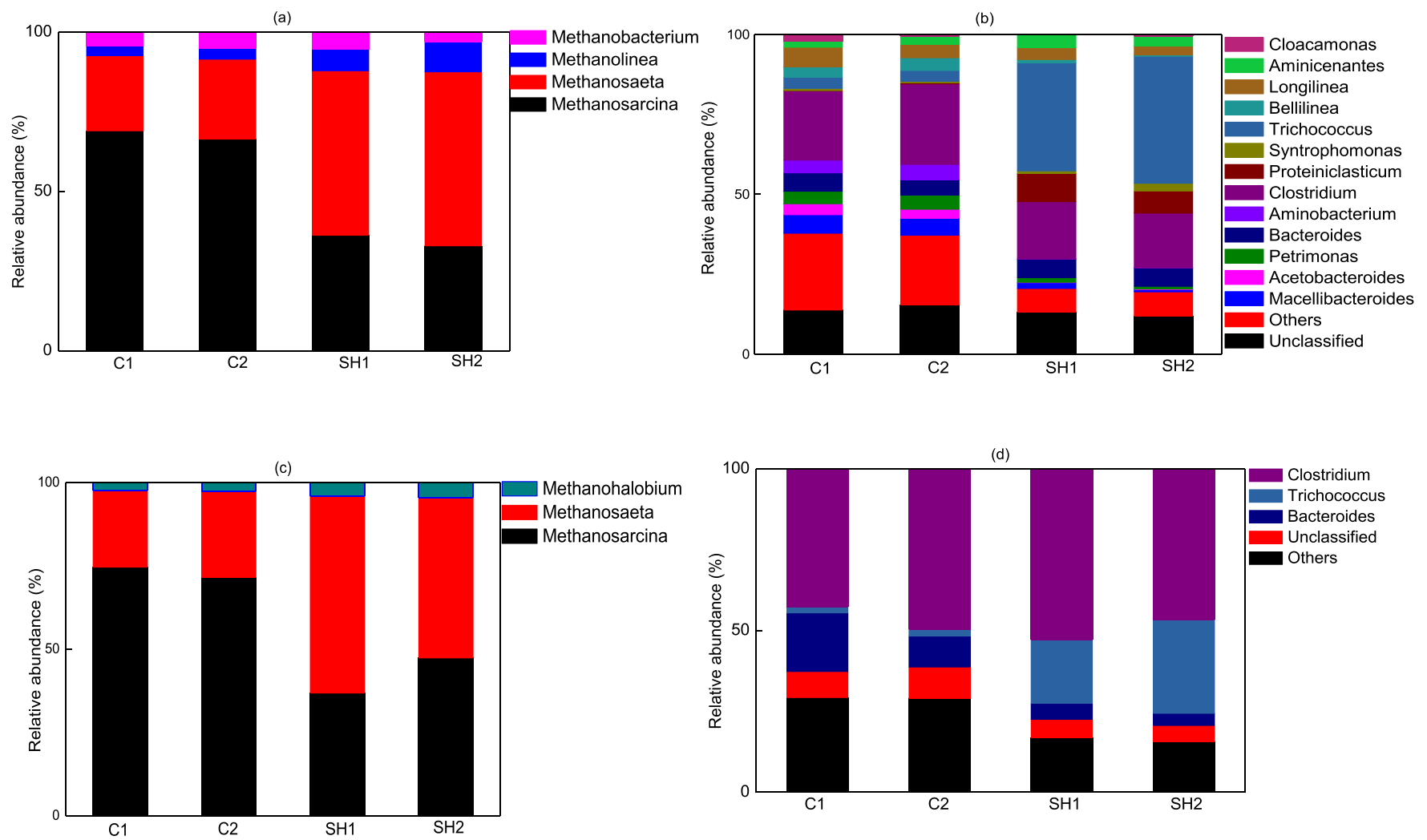

Figure 2. Genus level classification of the samples. (a) Archaeal genera and (b) bacterial genera based on 16S rRNA genes analysis; (c) archaeal genera and (d) bacterial genera based on proteomic analysis. Genera making up less than $1 \%$ of total composition were classified as "others."

acidification of glucose with and without $\mathrm{SH}$ was compared. As shown in Figure S4a, the addition of SH did not show obvious effects on the concentration and composition of VFA $(p<$ 0.05 ). Therefore, it could be concluded that $\mathrm{SH}$ did not affect the acidification step. The methanation of both $\mathrm{H}_{2} / \mathrm{CO}_{2}$ and acetate was also studied by the enriched cultures. Figure $\mathrm{S} 4 \mathrm{~b}$ and $\mathrm{c}$ show that the methane production rate of acetate by the enriched culture with $\mathrm{SH}$ was higher than that by the enriched culture in the control reactor. However, $\mathrm{SH}$ did not have an obvious influence on the methane production rate of $\mathrm{H}_{2} / \mathrm{CO}_{2}$. Therefore, $\mathrm{SH}$ selectively promoted methanation of acetate, while it did not affect methanation of $\mathrm{H}_{2} / \mathrm{CO}_{2}$. The methanogenic pathway was further evaluated by stable carbon isotopic analysis. An increase in $\alpha_{\mathrm{c}}$ means a shift to hydrogenotrophic methanogenesis. ${ }^{25}$ As shown in Figure S5, SH resulted in a significantly higher $\alpha_{\mathrm{c}}$ for each sampling date compared to the control reactor, which suggested $\mathrm{SH}$ enhanced hydrogenotrophic methanogenesis. However, Figure $\mathrm{S} 4$ did not show an increased methane production rate of $\mathrm{H}_{2}$ / $\mathrm{CO}_{2}$ by $\mathrm{SH}$. It should be noted that Figure $\mathrm{S} 4$ was obtained by using molecular $\mathrm{H}_{2}$ as a substrate, which indicated the traditional IHT process was not promoted by SH. It was possible that DIET was achieved with the presence of $\mathrm{SH}$, and therefore more $\mathrm{H}^{+}, \mathrm{e}^{-}$, and $\mathrm{CO}_{2}$ were directly utilized for methane production through hydrogenotrophic methanogenesis. A previous study also showed the methanogen Methanosaeta (formerly called Methanothrix) involved in DIET could only utilize $\mathrm{H}^{+}$and $\mathrm{e}^{-}$but not molecular $\mathrm{H}_{2}$ for hydrogenotrophic methanogenesis. ${ }^{26,27}$ Therefore, it could be concluded that $\mathrm{SH}$ facilitated DIET in the $\mathrm{AD}$ process, and further microbial and proteomic analysis also verified this point. It should also be mentioned that the enhancement of the methane production rate of acetate by $\mathrm{SH}$ as shown in Figure S4b was also possible by DIET, since a previous study showed the methane production rate of acetate was higher due to DIET with the addition of magnetite. ${ }^{28}$ In this case, acetate would not be consumed directly by aceticlastic methanogens, but through syntrophic growth of bacteria and methanogen via DIET. Overall, the above results showed the enhanced methane production rate of glucose by $\mathrm{SH}$ was correlated to the promotion of methanogenesis but not acidification.

Effects of SH on the Microbial Community Compositions. The phylum level identification based on highthroughput sequencing of $16 \mathrm{~S}$ rRNA genes analysis showed that all the samples were dominated by Firmicutes, Euryarchaeota, Bacteroidetes, Chloroflexi, Aminicenantes, Proteobacteria, and Synergistetes (Figure S6). SH caused a significant increase in the relative abundance of Firmicutes and resulted in obvious decrease in the relative abundances of Synergistetes, Bacteroidetes, and Euryarchaeota. The phylum Firmicutes contains acidogenic and acetogenic bacteria capable of converting a wide range of organics to VFA and subsequently to acetate, $\mathrm{H}_{2}$, and $\mathrm{CO}_{2}$, and the enrichment could be contributed to the higher methane production rate with $\mathrm{SH}$ since these bacteria might achieve syntrophic growth with methanogens, which could efficiently convert VFA to acetate and facilitate methane production. ${ }^{29}$ Although $\mathrm{SH}$ increased the methane production rate, strangely it led to the decrease in the relative abundance of Euryarchaeota, which contains methanogens. $^{30}$ It should be remarked that lower relative abundance does not mean low absolute concentration of methanogens, which is discussed in the following part by qPCR analysis. 
Identification of both bacteria and archaea was also conducted at the genus level (Figure $2 \mathrm{a}$ and $\mathrm{b}$ ). Four archaeal genera, Methanobacterium, Methanolinea, Methanosaeta, and Methanosarcina, were detected. The hydrogenotrophic methanogens Methanobacterium and Methanolinea accounted for less than $10 \%$ of the archaea, ${ }^{31}$ and a slight increase of the relative abundance of Methanolinea was observed when $\mathrm{SH}$ was present. Methanosaeta, the only known strict acetoclastic methanogen, ${ }^{32}$ increased significantly with the addition of SH (from $24 \%$ to $50 \%$ ). By contrast, Methanosarcina, which could use both $\mathrm{H}_{2} / \mathrm{CO}_{2}$ and acetate for methane production, ${ }^{33}$ was greatly reduced from $72-75 \%$ to $37-48 \%$. Recent studies showed that the conductive materials could enrich Methanosaeta, which could accept $\mathrm{e}^{-}$via DIET for the reduction of $\mathrm{CO}_{2}$ to methane, ${ }^{26,27}$ and the results also indicated that $\mathrm{SH}$ might stimulate DIET. However, the known bacteria Geobacter spp. and Syntrophus aciditrophicus, which could perform DIET, ${ }^{4}$ were not found in the present study. The bacterial genus Trichococcus, belonging to Firmicutes, was obviously enriched with SH. Trichococcus could produce lactate, acetate, and ethanol from glucose, ${ }^{34}$ but the ability to achieve extracellular electron transport has not been reported. It seems that the exact role of Trichococcus requires further investigation. The enrichment of Trichococcus and Methanosaeta was further verified by label-free proteomic analysis (Figure $2 \mathrm{c}$ and $\mathrm{d}$ ). The proteomic analysis also indicated that the genus Clostridium played important roles in $\mathrm{AD}$ with and without $\mathrm{SH}$, considering its high relative abundances (50-60\%) in both cases. The changes of subordinate microbial genera were discussed in the Supporting Information by both $16 \mathrm{~S}$ rRNA genes and proteomic analysis. Overall, the results showed that $\mathrm{SH}$ changed the microbial community structures of $\mathrm{AD}$, which could be related with the higher methane production rate. However, the intrinsic mechanism for enhanced methane production by $\mathrm{SH}$ deserves further elucidation in view of the changes in metabolic pathways.

Effects of SH on Metabolic Pathways As Revealed by Proteomic Analysis. In total, 1711 proteins were identified from all the samples, and 262 of the 1711 proteins were identified as differentially expressed proteins with 101 upregulated and 161 down-regulated proteins by comparing the samples with $\mathrm{SH}$ to those without SH (Figure 3). Table S4 shows all the differentially expressed proteins. GO enrichment analysis showed that $\mathrm{SH}$ significantly enriched proteins that were involved in cellular component organization or biogenesis

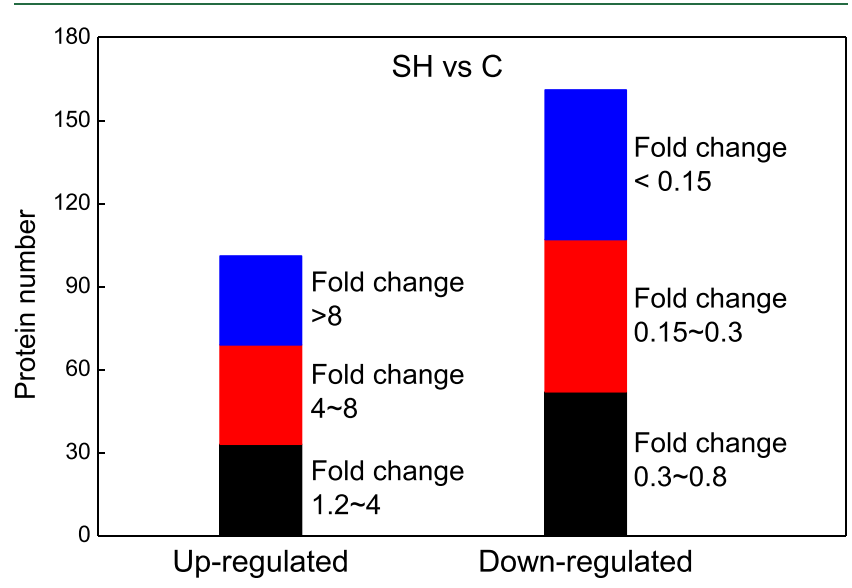

Figure 3. Numbers of up-regulated and down-regulated proteins. and metabolic process belonging to biological function, cell part and membrane belonging to the cellular component, and binding and structural molecular activity belonging to molecular function (Figure S7a). KEGG pathway enrichment analysis further showed that $\mathrm{SH}$ enriched proteins that were involved in various pathways, such as methane production, glycolysis/gluconeogenesis, and carbon metabolism, which were directly related with the efficiency of $\mathrm{AD}$ (Figure S7b). The above results provided a general overview of the effects of $\mathrm{SH}$ on the metabolic pathways. Detailed analysis based on the KEGG pathway was subsequently conducted to understand the process better.

As shown in Tables S4 and S5, 60 of the 101 up-regulated proteins were originated from methanogens, which included enzymes involved in both hydrogenotrophic and aceticlastic methanogenesis (e.g., Acetyl-CoA synthetase and methylenetetrahydromethanopterin dehydrogenase), ${ }^{35}$ most of which (57) were originated from Methanosaeta. It was consistent with the enrichment of Methanosaeta by microbial community analysis. Methanosaeta is strict aceticlastic methanogen. However, the up-regulated protein responsible for hydrogenotrophic methanogenesis (methylenetetrahydromethanopterin dehydrogenase) was found. Although Methanosaeta could not use molecular $\mathrm{H}_{2}$, it could accept $\mathrm{e}^{-}$produced by DIET and $\mathrm{H}^{+}$ to produce methane through hydrogenotrophic methanogenesis. $^{26,27}$ The proteomic analysis demonstrated the presence of DIET with $\mathrm{SH}$ in a mixed culture system. Although some up-regulated proteins responsible for hydrogenotrophic methanogenesis were detected from Methanosarcina (Table S4), the proteomic analysis could not verify whether Methanosarcina was involved in DIET since Methanosarcina could achieve hydrogenotrophic methanogensis through both IHT and DIET.

It should be noted that the presence of bacteria that could achieve DIET was necessary in order to provide $\mathrm{H}^{+}$and $\mathrm{e}^{-}$to Methanosaeta. As Trichococcus was enriched and a possible partner of Methanosaeta, the proteins originated from Trichococcus were analyzed. It was found that 17 proteins that originated from Trichococcus were enriched, and some of them (e.g., glucose-6-phosphate isomerase and enolase) were involved in glycolysis, which was consistent with its ability for the fermentation of glucose as previously reported. ${ }^{34}$ However, the proteins relating to e-pilin and cytochrome $\mathrm{C}$, which were involved in DIET, ${ }^{27}$ were not detected. The absence of such proteins did not imply an absence of DIET, ${ }^{9}$ and they might be substituted by hydrochar for electron transfer. There were several uncharacterized proteins originated from Trichococcus, and it is still not known whether they were responsible for DIET. As previously mentioned, Clostridium was also dominant in the samples. It was found that a protein correlated to c-type cytochrome was enriched in Clostridium. c-type cytochromes are known to be involved in electron transport, and some of them contributed to DIET. ${ }^{10}$ However, the cytochrome C551 found in the present study was reported to shuttle electrons within bacterial periplasm, ${ }^{36}$ while it is still unclear whether it can mediate extracellular electron transfer. Nevertheless, the proteomic analysis evidenced that $\mathrm{SH}$ changed the metabolic pathway of Clostridium, although its relative abundance was not obviously affected. The above results clearly showed that Methanosaeta was involved in DIET. Although there was no direct proteomic evidence for the participation of Trichococcus in DIET, its significant enrichment with the addition of hydrochar supported the high 


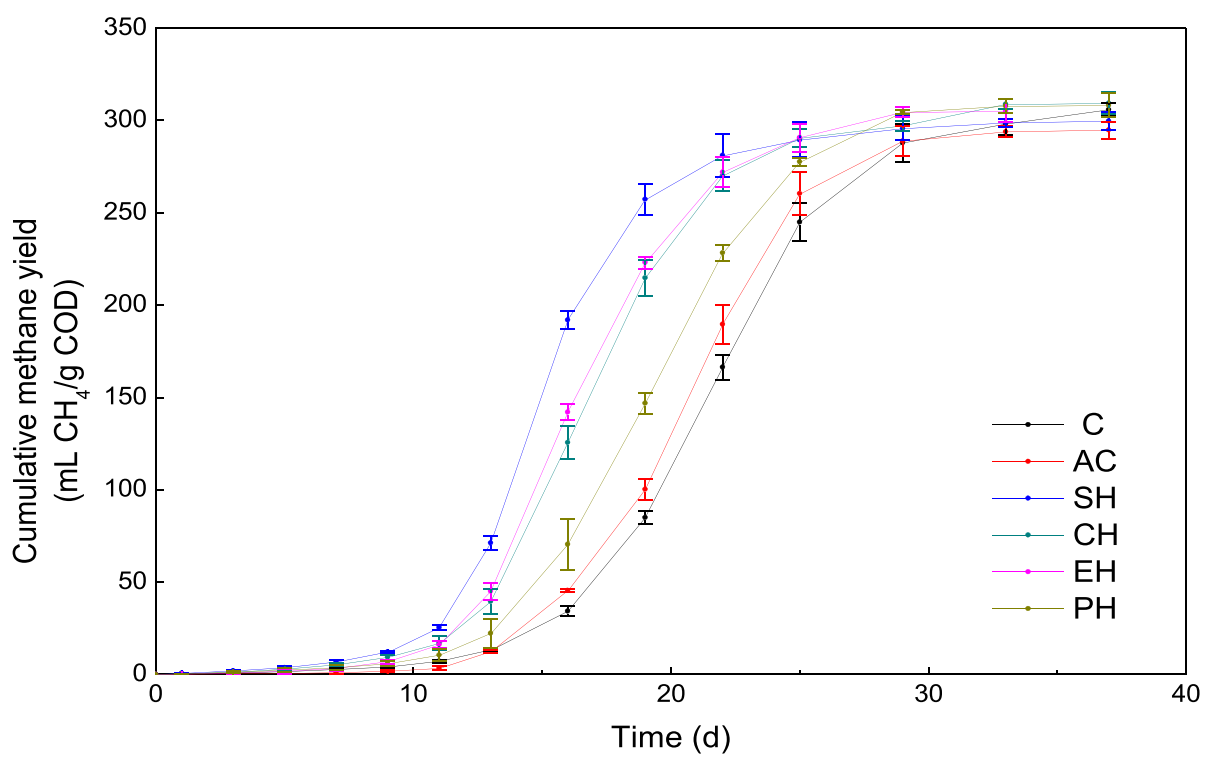

Figure 4. Cumulative methane production from glucose affected by different hydrochars and AC.

likelihood of its involvement in DIET together with Methanosaeta. In addition, it was proved that the genus Trichococcus contains microbes that could achieve extracellular electron transfer (EET), which also suggested that the genus Trichococcus probably participated in DIET in the present study (Supporting Information).

Effects of SH on the Key Microbial Populations As Revealed by qPCR Analysis. qPCR analysis was conducted to quantify the key microbial populations (Figure S8). The concentrations of both bacteria and archaea were higher in the bottles with $\mathrm{SH}$ compared to control, which indicated the stimulation of microbial growth by SH. Although the microbial analysis showed that the relative abundance of archaea (Euryarchaeota) was decreased in the presence of $\mathrm{SH}$, the qPCR analysis demonstrated that its absolute concentration was higher, which was consistent with the higher methane production rate. The increase of MST (Methanosaeta) and decrease of MSC (Methanosarcina) in the presence of hydrochar was also demonstrated by qPCR analysis, further demonstrating the important role of Methanosaeta in the $\mathrm{AD}$ process with $\mathrm{SH}$.

Main Characteristics of Hydrochar Related to the Promotion of the AD Process. The methane production with hydrochars obtained from HTL of different feedstocks as well as AC was compared, and the results are shown in Figure 4 and Table S6. All the tested hydrochars and AC themselves did not produce methane (data not shown). $\mathrm{SH}, \mathrm{CH}$, and $\mathrm{EH}$ significantly promoted the methane production rate by $39 \%$, $15 \%$, and $20 \%(p<0.05)$, respectively, and they also decreased the duration of the lag phase. However, $\mathrm{PH}$ and $\mathrm{AC}$ did not show obvious enhancement on the methane production rate (Table S6). Moreover, relatively higher $\mathrm{pH}$ and faster consumption of VFA were also found for $\mathrm{SH}, \mathrm{CH}$, and $\mathrm{EH}$, as seen in Figure S9. Although previous studies suggested that AC could achieve DIET to promote the methane production rate from various substrates, ${ }^{37}$ the present study did not show any positive effect on the methane production rate, which was consistent with a previous study using glucose as a substrate under mesophilic conditions. ${ }^{38}$ Nevertheless, the above results showed that hydrochar obtained from the HTL of different feedstocks had varying promotion effects on methane production. Therefore, the characteristics of hydrochar and AC were determined to better identify potential reasons in different promotion effects on methane production. Previous studies suggested that conductivity was crucial to achieving DIET. ${ }^{7,37}$ However, only AC had notable conductivity (3732 $\mu \mathrm{S} \mathrm{cm} \mathrm{cm}^{-1}$ ) while the conductivity of all the hydrochars could not be detected. The lack of conductivity of hydrochars could be due to the lower hydrothermal temperature. For instance, a previous study showed only a pyrolysis temperature higher than $600{ }^{\circ} \mathrm{C}$ could form biochar with obvious conductivity that could achieve direct electron transfer. ${ }^{39} \mathrm{AC}$ was produced at a high pyrolysis temperature $\left(>700{ }^{\circ} \mathrm{C}\right),{ }^{40}$ and therefore it had high conductivity. The above results showed that conductivity was not correlated to the enhancement of methane production rate.

Recent studies also suggested that redox property could affect the DIET. ${ }^{18,39}$ Therefore, a cyclic voltammetry analysis was conducted to examine the redox properties of hydrochars and AC (Figure 5a). A pair of redox peaks were observed for each hydrochar, while they were not found for AC. However, $\mathrm{PH}$ had higher peaks for the redox property compared to the other hydrochars, while it did not promote methane production. The redox properties of hydrochar were further quantified by $\mathrm{I}_{2} / \mathrm{NaBH}_{4}$ titration (Figure $\left.5 \mathrm{~b}\right){ }^{17}$ and $\mathrm{PH}$ still had the highest redox capacity considering the highest electron donating capacity (EDC) and electron accepting capacity (EAC), which was consistent with cyclic voltammetry (CV) results. It seems that the redox properties of hydrochar were also not correlated to the enhancement of the methane production rate.

It should be noted that both $\mathrm{CV}$ and $\mathrm{I}_{2} / \mathrm{NaBH}_{4}$ titration analysis gave the total redox properties of hydrochars. The oxygen-containing functional groups are related to the redox property, while it is possible that not all the oxygen-containing functional groups were accessible to the microbes. For instance, hydrochar and AC contained abundant pores with a size less than $35 \mathrm{~nm}$ (contributed to more than 50\% of the BET surface area, Figure S10, Table S1), which was much smaller than microbes. ${ }^{41}$ Therefore, the surface functional groups were analyzed by FTIR (Figure 6). The oxygencontaining functional groups correlating to redox properties 

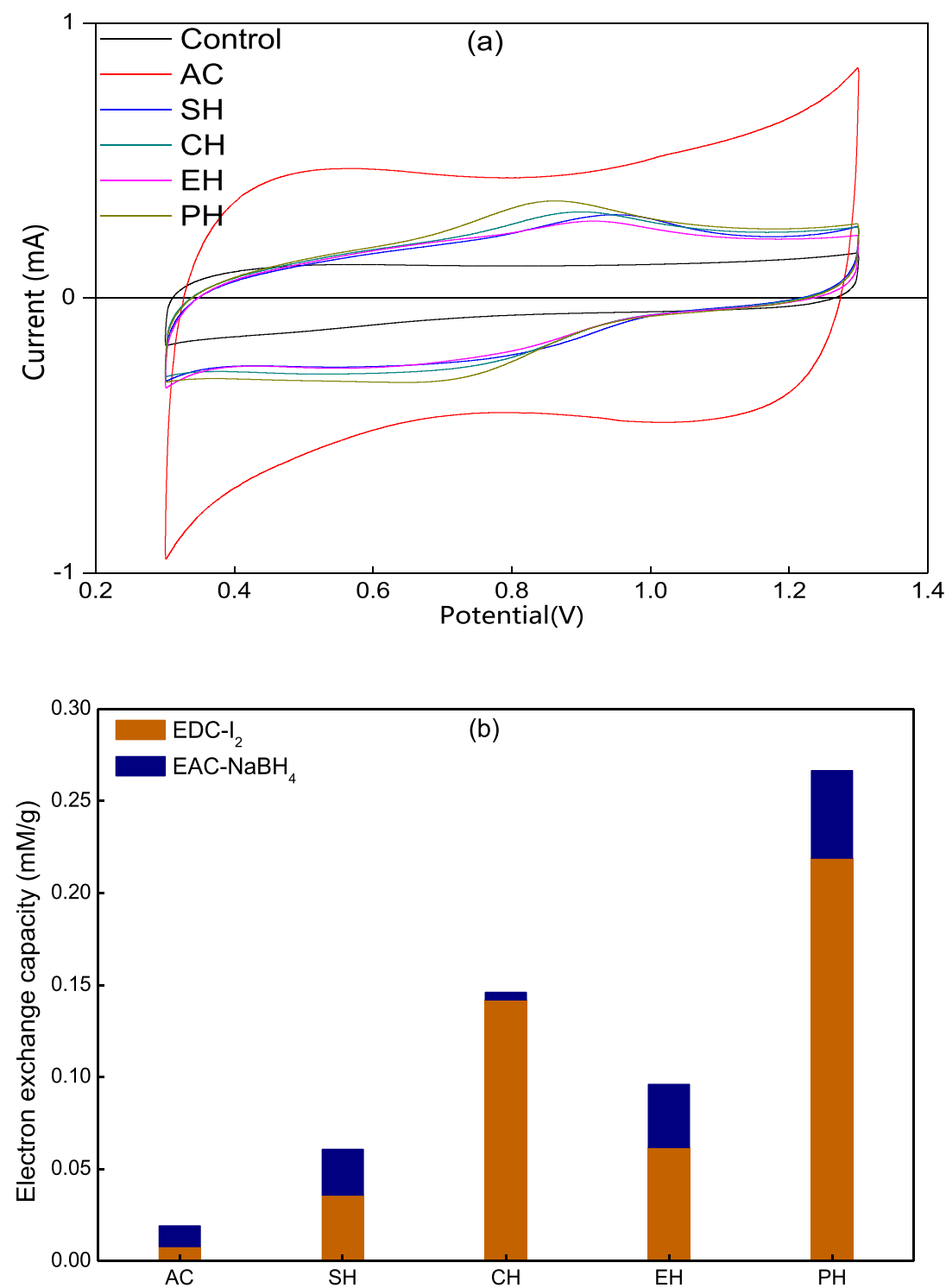

Figure 5. Redox properties of hydrochars and AC: (a) Cyclic voltammetry curves; (b) EDC and EAC determined by $\mathrm{I}_{2}$ titration and $\mathrm{NaBH}_{4}$ titration, respectively.

include $\mathrm{C}-\mathrm{O}, \mathrm{C}=\mathrm{O}$, and $\mathrm{C}-\mathrm{OH},{ }^{18,42}$ which were abundant in $\mathrm{SH}, \mathrm{CH}$, and $\mathrm{EH}$ but not in $\mathrm{PH}$ and $\mathrm{AC}$. It is obvious that $\mathrm{PH}$ contained less redox functional groups on its surface, which could account for its incapability for the enhancement of methane production rate. Quantitative XPS showed that AC and $\mathrm{PH}$ had the lowest surface $\mathrm{O} / \mathrm{C}$ atomic ratios, indicating they were more reduced than the other hydrochars (Table 1 and Figure S11). It also showed that $\mathrm{PH}$ and $\mathrm{AC}$ contained lower surface oxygen-containing functional groups compared to the other hydrochars. The highest abundance of surface oxygen-containing functional groups (especially $\mathrm{C}=\mathrm{O}$ ) was found in $\mathrm{SH}$, which was consistent with its highest capacity to promote biogas production. Figure S12a further showed the surface oxygen-containing functional groups were significantly positively correlated to methane production rates with a $p$ value of 0.001 .

It is noteworthy that $\mathrm{CV}$ and quantification of the redox property have been employed to analyze the redox properties of biochar, hydrochar, and AC in previous studies, ${ }^{18,19,39}$ while our results showed that they were not necessarily correlated to the promotion of biological process. The surface functional groups analysis based on FTIR and XPS provided valuable information to understand the role of hydrochar in $\mathrm{AD}$. The other characteristics of hydrochar were also measured including $\mathrm{BET}$ and $\mathrm{pH}$ (Table S1), which were shown to be not correlated to the promotion of the methane production rates (Figure $S 12 b$ and $c, p>0.05$ ). Overall, the present study revealed that the surface redox functional groups of hydrochar were more significantly correlated to its promotion on methane production rate. For instance, $\mathrm{SH}$ contained more surface redox functional groups compared to $\mathrm{CH}, \mathrm{EH}$, and $\mathrm{PH}$, and therefore it performed better in enhancing the methane production rate. The surface redox functional groups are related with quinone and hydroquinone moieties, which are able to donate and accept electrons and thus make hydrochar redox active. ${ }^{43,44}$ Therefore, hydrochar can accept electrons from bacteria by oxidation of organics and also donate electrons to methanogens for methane production, behaving as an electron shuttle for DIET to promote the methane production rate. The result was consistent with a previous 


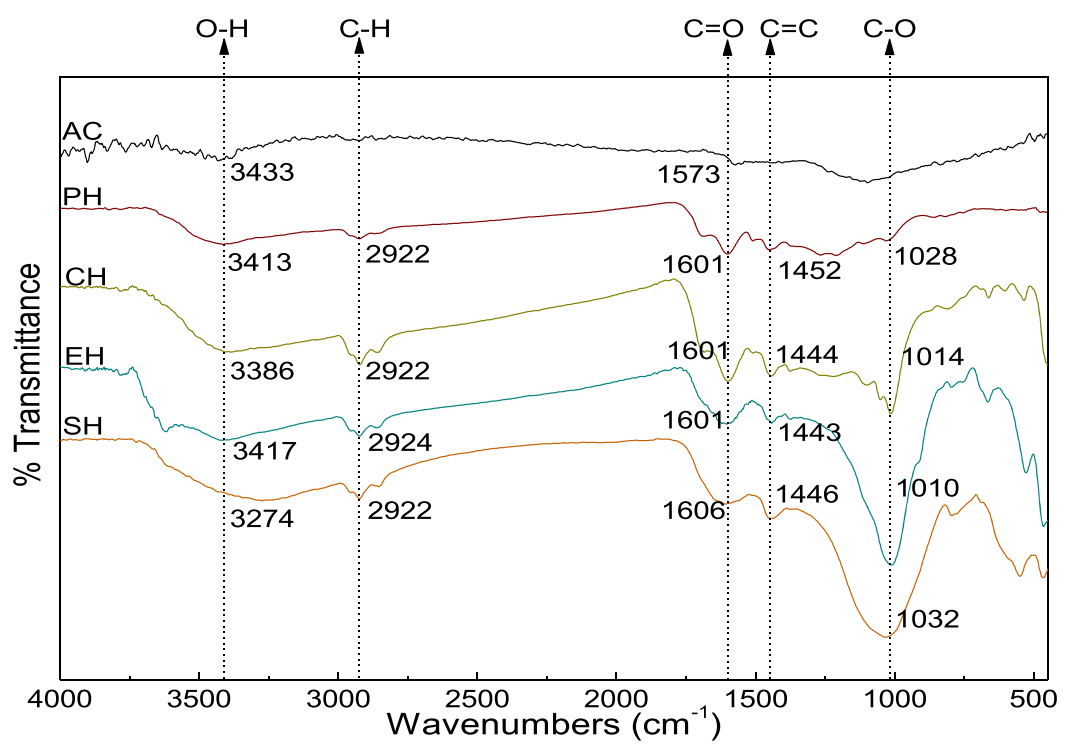

Figure 6. FTIR analysis of hydrochars and AC.

Table 1. Surface O/C Ratios by XPS, C-O Bond Percentages by Deconvolution of XPS C 1s Specrta and Electrical Conductivity (EC; Three Replicates Were Used for the Measurements)

\begin{tabular}{|c|c|c|c|c|c|c|}
\hline & \multicolumn{5}{|c|}{$\mathrm{C}-\mathrm{O}$ bonds (\%) } & \multirow[b]{2}{*}{$\mathrm{EC}\left(\mu \mathrm{S} \mathrm{cm}^{-1}\right)$} \\
\hline & O/C (by XPS) & $\mathrm{C}-\mathrm{OH}$ & $\mathrm{C}=\mathrm{O}$ & $\mathrm{O}-\mathrm{C}=\mathrm{O}$ & total & \\
\hline $\mathrm{AC}$ & $0.133 \pm 0.011$ & $33.3 \pm 1.5$ & $4.1 \pm 0.2$ & $5.8 \pm 0.3$ & $43.2 \pm 1.5$ & $3732 \pm 120$ \\
\hline $\mathrm{SH}$ & $0.444 \pm 0.035$ & $56.8 \pm 2.3$ & $22.8 \pm 1.1$ & $5.2 \pm 0.2$ & $84.8 \pm 2.6$ & \\
\hline $\mathrm{CH}$ & $0.286 \pm 0.021$ & $44.9 \pm 1.8$ & $6.6 \pm 0.3$ & $6.6 \pm 0.3$ & $58.2 \pm 1.8$ & \\
\hline $\mathrm{EH}$ & $0.420 \pm 0.015$ & $45.8 \pm 3.1$ & $7.0 \pm 0.2$ & $6.7 \pm 0.5$ & $59.6 \pm 3.1$ & \\
\hline $\mathrm{PH}$ & $0.250 \pm 0.011$ & $32.2 \pm 2.2$ & $9.0 \pm 0.5$ & $3.2 \pm 0.1$ & $44.5 \pm 2.3$ & \\
\hline
\end{tabular}

study, which showed redox-active biochar could serve as an electron shuttle and accelerate DIET between Geobacter metallireducens and Methanosarcina in the coculture system. ${ }^{45}$

Implications. Hydrochar is attracting much attention in recent years due to its potential application in environmental remediation, energy storage, and climate change mitigation. ${ }^{15}$ Regarding the environmental applications of hydrochar, previous studies mainly investigated its utilization as adsorbents for inorganic and organic pollutants. ${ }^{46}$ The application of hydrochar in biological processes is an emerging field that has tremendous potentials. The present study demonstrated that $\mathrm{SH}$ facilitated the $\mathrm{AD}$ of glucose by surface oxygen-containing functional group-mediated DIET. The demonstration of DIET in the $\mathrm{AD}$ process is challenging since it is a mixed culture system with various microbes. Although recent studies investigated the addition of various materials to the $\mathrm{AD}$ process to achieve DIET for increasing methane production rate, only indirect evidence of DIET is available in most studies. ${ }^{9}$ A recent review suggested that the combination of different methods is necessary to confirm the presence of DIET, ${ }^{9}$ which was the case in the present study. Stable carbon isotopic analysis showed that $\mathrm{SH}$ increased hydrogenotrophic methanogenesis but did not affect IHT considering unchanged $\mathrm{H}_{2}$ consumption rate, which indicated the presence of DIET. Further microbial and proteomic analysis showed $\mathrm{SH}$ enriched the strict acetoclastic methanogen Methanosaeta with up-regulated proteins involved in hydrogenotrophic methanogenesis, also demonstrating the presence of DIET considering the ability of Methanosaeta to use $\mathrm{H}^{+}$and $\mathrm{e}^{-}$through hydrogenotrophic methanogenesis. The present study provided evidence for DIET facilitated by SH in a mixed culture system and also showed that the genus Trichococcus contains microbes that could achieve EET. However, there was no direct evidence for the involvement of Trichococcus in DIET. Further study by metagenomic analysis deserves to be carried out to extract the genomes of enriched bacteria and reveal their potential metabolic pathways, which would possibly discover the bacteria involved in DIET. ${ }^{47,48}$ It is also deserved to attempt to isolate the enriched bacteria and investigate their roles in DIET. However, it might be difficult since only a few well characterized model microbes (Geobacter spp. and Syntrophus aciditrophicus) were demonstrated to be involved in DIET, and there are no studies reporting on which microbes have been recovered in culture with DIET as the enrichment/isolation procedure. ${ }^{10}$ In addition, several methods to identify electrochemically active bacteria, including U-tube microbial fuel cells and voltagebased screening assays designed using MFC engineering principles, could also be used to demonstrate the potential involvement of Trichococcusin in DIET. ${ }^{49,50}$ Furthermore, the present study mainly focused on the demonstration of DIET in the hydrochar-facilitated $\mathrm{AD}$ process, and the role of adsorption in such a process was not considered. The role of adsorption in the present study might be ignored since hydrochar had a much lower BET surface area $\left(<100 \mathrm{~m}^{2} / \mathrm{g}\right)$ compared with that of GAC $\left(\sim 1000 \mathrm{~m}^{2} / \mathrm{g}\right)$ and might have very low adsorptivity for glucose and acetate with high polarity.

The higher methane production rate with $\mathrm{SH}$ means the organics can be converted to methane faster. Therefore, lower hydraulic retention time (HRT) or higher organic loading rate 
(OLR) can be applied in the continuous experiments with $\mathrm{SH}$ in order to get the same organic removal efficiency, which would decrease the cost for wastewater treatment. Further study should be conducted in continuous experiments with various operational conditions (HRT, OLR, substrate type, reactor configuration, etc.) to investigate the promotion effects of $\mathrm{SH}$ on reactor performances. Furthermore, it was known that acidification was the common problem of anaerobic reactors, and it generally takes a long time for the recovery of the reactor due to the low $\mathrm{pH}$ and the presence of high concentrations of VFA. ${ }^{4,24}$ The addition of SH could be a simple yet effective solution to accelerate the recovery of acidified anaerobic reactors, since $\mathrm{SH}$ accelerated the degradation of VFA as seen in Figure $1 \mathrm{c}$ and $d$ and Figure S3b. In addition, hydrochar could be potentially applied for the biodegradation of organic contaminants such as phenols and azo dyes in wastewater because their degradation has been reported to be enhanced by additive materials with redox properties. $^{51,52}$ For the real organic wastes/wastewater, the mechanisms for the application of hydrochar to enhance methane production might be more complex considering its potential to adsorb some inhibitory compounds such as ammonia. ${ }^{53}$ More research advancing the application of hydrochar in the $\mathrm{AD}$ process should be conducted. It should be noted that not all the hydrochars from different feedstocks could promote the methane production rate, and the abundant surface oxygen-containing functional groups of hydrochar are crucial. The methods (e.g., $\mathrm{HNO}_{3}$ and $\mathrm{H}_{2} \mathrm{O}_{2}$ pretreatment) to modify the hydrochar to increase surface oxygen-containing functional groups could be explored in future studies to further enhance $\mathrm{AD}$ efficiency. ${ }^{18,20,54}$

\section{ASSOCIATED CONTENT}

\section{(s) Supporting Information}

The Supporting Information is available free of charge at https://pubs.acs.org/doi/10.1021/acs.est.0c00112.

Description of stable carbon isotope analysis, highthroughput sequencing of 16S rRNA genes, label-free proteomic analysis, qPCR analysis, evaluation of the extracellular electron transfer capacity of Trichococcus spp., analytical methods, Figures $\mathrm{S} 1-\mathrm{S} 13$, and Tables S1-S7 (PDF)

Upregulated and downregulated proteins (XLSX)

\section{AUTHOR INFORMATION}

\section{Corresponding Author}

Gang Luo - Shanghai Key Laboratory of Atmospheric Particle Pollution and Prevention (LAP3), Department of Environmental Science and Engineering, Fudan University, Shanghai 200438, China; Shanghai Technical Service Platform for Pollution Control and Resource Utilization of Organic Wastes, Shanghai 200438, China; Shanghai Institute of Pollution Control and Ecological Security, Shanghai 200092, People's Republic of China; (1) orcid.org/0000-0002-97119619; Phone: +86-21-31248912; Email: gangl@ fudan.edu.cn

\section{Authors}

Shuang Ren - Shanghai Key Laboratory of Atmospheric Particle Pollution and Prevention (LAP3), Department of Environmental Science and Engineering, Fudan University, Shanghai 200438, China
Muhammad Usman - Shanghai Key Laboratory of Atmospheric Particle Pollution and Prevention (LAP3), Department of Environmental Science and Engineering, Fudan University, Shanghai 200438, China

Daniel C. W. Tsang - Department of Civil and Environmental Engineering, The Hong Kong Polytechnic University, Kowloon,

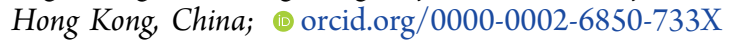

Sompong O-Thong - Shanghai Key Laboratory of Atmospheric Particle Pollution and Prevention (LAP3), Department of Environmental Science and Engineering, Fudan University, Shanghai 200438, China; Department of Biology, Faculty of Science, Thaksin University, Phathalung 93110, Thailand

Irini Angelidaki - Department of Environmental Engineering, Technical University of Denmark, DK-2800 Kgs Lyngby,

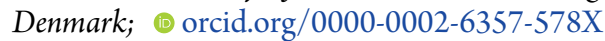

Xiangdong Zhu - Shanghai Key Laboratory of Atmospheric Particle Pollution and Prevention (LAP3), Department of Environmental Science and Engineering, Fudan University, Shanghai 200438, China; Shanghai Technical Service Platform for Pollution Control and Resource Utilization of Organic

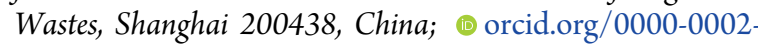
8536-7690

Shicheng Zhang - Shanghai Key Laboratory of Atmospheric Particle Pollution and Prevention (LAP3), Department of Environmental Science and Engineering, Fudan University, Shanghai 200438, China; Shanghai Technical Service Platform for Pollution Control and Resource Utilization of Organic Wastes, Shanghai 200438, China; Shanghai Institute of Pollution Control and Ecological Security, Shanghai 200092, People's Republic of China; 이잉.org/0000-0001-99941385

Complete contact information is available at: https://pubs.acs.org/10.1021/acs.est.0c00112

\section{Notes}

The authors declare no competing financial interest.

\section{ACKNOWLEDGMENTS}

This research was supported by the National Key Research and Development Program of China (Grant No. 2017YFC0212900, 2017YFC0212200), the National Natural Science Foundation of China (31970117), and Science and Technology Commission of Shanghai Municipality (19DZ1204704).

\section{REFERENCES}

(1) Madsen, M.; Holm-Nielsen, J. B.; Esbensen, K. H. Monitoring of anaerobic digestion processes: A review perspective. Renewable Sustainable Energy Rev. 2011, 15 (6), 3141-3155.

(2) Ye, M.; Liu, J.; Ma, C.; Li, Y. Y.; Zou, L.; Qian, G.; Xu, Z. P. Improving the stability and efficiency of anaerobic digestion of food waste using additives: A critical review. J. Cleaner Prod. 2018, 192, 316-326.

(3) Appels, L.; Lauwers, J.; Degrève, J.; Helsen, L.; Lievens, B.; Willems, K.; Van Impe, J.; Dewil, R. Anaerobic digestion in global bioenergy production: Potential and research challenges. Renewable Sustainable Energy Rev. 2011, 15, 4295-4301.

(4) Jing, Y.; Wan, J.; Angelidaki, I.; Zhang, S.; Luo, G. iTRAQ quantitative proteomic analysis reveals the pathways for methanation of propionate facilitated by magnetite. Water Res. 2017, 108, 212221.

(5) Mao, C. L.; Feng, Y. Z.; Wang, X. J.; Ren, G. X. Review on research achievements of biogas from anaerobic digestion. Renewable Sustainable Energy Rev. 2015, 45 (2015), 540-555. 
(6) Zhang, Q.; Hu, J.; Lee, D. J. Biogas from anaerobic digestion processes: Research updates. Renewable Energy 2016, 98, 108-119.

(7) Barua, S.; Dhar, B. R. Advances towards understanding and engineering direct interspecies electron transfer in anaerobic digestion. Bioresour. Technol. 2017, 244, 698-707.

(8) Zhao, Z.; Li, Y.; Quan, X.; Zhang, Y. Towards engineering application: Potential mechanism for enhancing anaerobic digestion of complex organic waste with different types of conductive materials. Water Res. 2017, 115, 266-277.

(9) Van Steendam, C.; Smets, I.; Skerlos, S.; Raskin, L. Improving anaerobic digestion via direct interspecies electron transfer requires development of suitable characterization methods. Curr. Opin. Biotechnol. 2019, 57, 183-190.

(10) Lovley, D. R. Syntrophy goes electric: Direct interspecies electron transfer. Annu. Rev. Microbiol. 2017, 71, 643-664.

(11) Luo, C.; Lü, F.; Shao, L.; He, P. Application of eco-compatible biochar in anaerobic digestion to relieve acid stress and promote the selective colonization of functional microbes. Water Res. 2015, 68, 710-718.

(12) Usman, M.; Chen, H.; Chen, K.; Ren, S.; Fan, J.; Clark, J.; Luo, G.; Zhang, S. Characterization and utilization of aqueous products from hydrothermal conversion of biomass for bio-oil and hydro-char production: A Review. Green Chem. 2019, 21, 1553-1572.

(13) Chen, H.; Wan, J.; Chen, K.; Luo, G.; Fan, J.; Clark, J.; Zhang, $\mathrm{S}$. Biogas production from hydrothermal liquefaction wastewater (HTLWW): Focusing on the microbial communities as revealed by high-throughput sequencing of full-length $16 \mathrm{~S}$ rRNA genes. Water Res. 2016, 106, 98-107.

(14) Wang, T.; Zhai, Y.; Zhu, Y.; Li, C.; Zeng, G. A review of the hydrothermal carbonization of biomass waste for hydrochar formation: Process conditions, fundamentals, and physicochemical properties. Renewable Sustainable Energy Rev. 2018, 90, 223-247.

(15) Zhang, S.; Zhu, X.; Zhou, S.; Shang, H.; Luo, J.; Tsang, D. C. W. Chapter 15 - Hydrothermal Carbonization for Hydrochar Production and Its Application. In Biochar from Biomass and Waste; Ok, Y. S., Tsang, D. C. W., Bolan, N., Novak, J. M., Eds.; Elsevier, 2019; pp 275-294.

(16) Xu, J.; Mustafa, A. M.; Lin, H.; Choe, U. Y.; Sheng, K. Effect of hydrochar on anaerobic digestion of dead pig carcass after hydrothermal pretreatment. Waste Manage. 2018, 78, 849-856.

(17) Mai, D.; Wen, R.; Cao, W.; Yuan, B.; Liu, Y.; Liu, Q.; Qian, G. Effect of heavy metal $(\mathrm{Zn})$ on redox property of hydrochar produced from lignin, cellulose, and d-Xylose. ACS Sustainable Chem. Eng. 2017, 5, 3499-3508.

(18) Wu, S.; Fang, G.; Wang, Y.; Zheng, Y.; Wang, C.; Zhao, F.; Jaisi, D. P.; Zhou, D. Redox-active oxygen-containing functional groups in activated carbon facilitate microbial reduction of ferrihydrite. Environ. Sci. Technol. 2017, 51, 9709-9717.

(19) Yuan, H. Y.; Ding, L. J.; Zama, E. F.; Liu, P. P.; Hozzein, W. N.; Zhu, Y. G. Biochar Modulates Methanogenesis through Electron Syntrophy of Microorganisms with Ethanol as a Substrate. Environ. Sci. Technol. 2018, 52, 12198-12207.

(20) Yan, Y.; Ma, X. L.; Cao, W. M.; Zhang, X.; Zhou, J. Z.; Liu, Q.; Qian, G. R. Identifying the reducing capacity of biomass derived hydrochar with different post-treatment methods. Sci. Total Environ. 2018, 643, 486-495.

(21) Lü, F.; Bize, A.; Guillot, A.; Monnet, V.; Madigou, C.; Chapleur, O.; Mazéas, L.; He, P.; Bouchez, T. Metaproteomics of cellulose methanisation under thermophilic conditions reveals a surprisingly high proteolytic activity. ISME J. 2014, 8, 88 .

(22) Angelidaki, I.; Sanders, W. Assessment of the anaerobic biodegradability of macropollutants. Rev. Environ. Sci. Bio/Technol. 2004, 3, 117-129.

(23) Hao, L. P.; Lü, F.; He, P. J.; Li, L.; Shao, L. M. Quantification of the inhibitory effect of methyl fluoride on methanogenesis in mesophilic anaerobic granular systems. Chemosphere 2011, 84, $1194-1199$.
(24) Mao, C.; Feng, Y.; Wang, X.; Ren, G. Review on research achievements of biogas from anaerobic digestion. Renewable Sustainable Energy Rev. 2015, 45, 540-555.

(25) Whiticar, M. J.; Faber, E.; Schoell, M. Biogenic methane formation in marine and freshwater environments: $\mathrm{CO}_{2}$ reduction vs. acetate fermentation-Isotope evidence. Geochim. Cosmochim. Acta 1986, 50, 693-709.

(26) Rotaru, A. E.; Shrestha, P. M.; Liu, F.; Shrestha, M.; Shrestha, D.; Embree, M.; Zengler, K.; Wardman, C.; Nevin, K. P.; Lovley, D. R. A new model for electron flow during anaerobic digestion: direct interspecies electron transfer to Methanosaeta for the reduction of carbon dioxide to methane. Energy Environ. Sci. 2014, 7, 408-415.

(27) Holmes, D. E.; Shrestha, P. M.; Walker, D. J. F.; Dang, Y.; Nevin, K. P.; Woodard, T. L.; Lovley, D. R. Metatranscriptomic evidence for direct interspecies electron transfer between Geobacter and Methanothrix species in methanogenic rice paddy soils. Appl. Environ. Microbiol. 2017, 83, No. e00223-17.

(28) Kato, S.; Hashimoto, K.; Watanabe, K. Methanogenesis facilitated by electric syntrophy via (semi)conductive iron-oxide minerals. Environ. Microbiol. 2012, 14, 1646-1654.

(29) Zhang, Z.; Gao, P.; Cheng, J.; Liu, G.; Zhang, X.; Feng, Y. Enhancing anaerobic digestion and methane production of tetracycline wastewater in EGSB reactor with GAC/NZVI mediator. Water Res. 2018, 136, 54-63.

(30) Du Toit, A. Divergent methanogenic archaea. Nat. Rev. Microbiol. 2016, 14, 667.

(31) Imachi, H.; Sakai, S.; Sekiguchi, Y.; Hanada, S.; Kamagata, Y.; Ohashi, A.; Harada, H. Methanolinea tarda gen. nov., sp. nov., a methane-producing archaeon isolated from a methanogenic digester sludge. Int. J. Syst. Evol. Microbiol. 2008, 58, 294-301.

(32) Huser, B. A.; Wuhrmann, K.; Zehnder, A. J. B. Methanothrix soehngenii gen. nov. sp. nov., a new acetotrophic non-hydrogenoxidizing methane bacterium. Arch. Microbiol. 1982, 132, 1-9.

(33) Opinion 63: Rejection of the type species Methanosarcina methanica (Approved Lists, 1980) and conservation of the genus Methanosarcina (Approved Lists, 1980) emend. Mah and Kuhn 1984 with Methanosarcina barkeri (Approved Lists, 1980) as the type species. Int. J. Syst. Bacteriol. 1986, 36, (3), 492-492,

(34) Brenner, D. J.; Krieg, N. R.; Staley, J. T. Bergey's Manual of Systematic Bacteriology; Springer: Boston, 2005.

(35) Li, A.; Chu, Y. n.; Wang, X.; Ren, L.; Yu, J.; Liu, X.; Yan, J.; Zhang, L.; Wu, S.; Li, S. J. B. f. B. A pyrosequencing-based metagenomic study of methane-producing microbial community in solid-state biogas reactor. Biotechnol. Biofuels 2013, 6, 3.

(36) Bertini, I.; Cavallaro, G.; Rosato, A. Cytochrome c: Occurrence and functions. Chem. Rev. 2006, 106, 90-115.

(37) Zhang, J.; Zhao, W.; Zhang, H.; Wang, Z.; Fan, C.; Zang, L. Recent achievements in enhancing anaerobic digestion with carbonbased functional materials. Bioresour. Technol. 2018, 266, 555-567.

(38) Yan, W.; Shen, N.; Xiao, Y.; Chen, Y.; Sun, F.; Kumar Tyagi, V.; Zhou, Y. The role of conductive materials in the start-up period of thermophilic anaerobic system. Bioresour. Technol. 2017, 239, 336344.

(39) Sun, T.; Levin, B. D. A.; Guzman, J. J. L.; Enders, A.; Muller, D. A.; Angenent, L. T.; Lehmann, J. Rapid electron transfer by the carbon matrix in natural pyrogenic carbon. Nat. Commun. 2017, 8, 14873.

(40) Allen, S. J.; Whitten, L.; McKay, G. The production and characterisation of activated carbons: A review. Dev. Chem. Eng. Miner. Process. 1998, 6, 231-261.

(41) Prado, A.; Berenguer, R; Esteve-Núñez, A. Electroactive biochar outperforms highly conductive carbon materials for biodegrading pollutants by enhancing microbial extracellular electron transfer. Carbon 2019, 146, 597-609.

(42) Zhang, X.; Xia, J.; Pu, J.; Cai, C.; Tyson, G. W.; Yuan, Z.; Hu, S. Biochar-mediated anaerobic oxidation of methane. Environ. Sci. Technol. 2019, 53, 6660-6668. 
(43) Tong, H.; Hu, M.; Li, F. B.; Liu, C. S.; Chen, M. J. Biochar enhances the microbial and chemical transformation of pentachlorophenol in paddy soil. Soil Biol. Biochem. 2014, 70, 142-150.

(44) Kappler, A.; Wuestner, M. L.; Ruecker, A.; Harter, J.; Halama, M.; Behrens, S. Biochar as an electron shuttle between bacteria and $\mathrm{Fe}(\mathrm{III})$ minerals. Environ. Sci. Technol. Lett. 2014, 1, 339-344.

(45) Chen, S. S.; Rotaru, A. E.; Shrestha, P. M.; Malvankar, N. S.; Liu, F. H.; Fan, W.; Nevin, K. P.; Lovley, D. R. Promoting interspecies electron transfer with biochar. Sci. Rep. 2015, 4, 7.

(46) Fang, J.; Zhan, L.; Ok, Y. S.; Gao, B. Minireview of potential applications of hydrochar derived from hydrothermal carbonization of biomass. J. Ind. Eng. Chem. 2018, 57, 15-21.

(47) Campanaro, S.; Treu, L.; Kougias, P. G.; Luo, G.; Angelidaki, I. Metagenomic binning reveals the functional roles of core abundant microorganisms in twelve full-scale biogas plants. Water Res. 2018, 140, 123-134.

(48) Jing, Y.; Campanaro, S.; Kougias, P.; Treu, L.; Angelidaki, I.; Zhang, S.; Luo, G. Anaerobic granular sludge for simultaneous biomethanation of synthetic wastewater and $\mathrm{CO}$ with focus on the identification of CO-converting microorganisms. Water Res. 2017, 126, 19-28.

(49) Zuo, Y.; Xing, D. F.; Regan, J. M.; Logan, B. E. Isolation of the exoelectrogenic bacterium Ochrobactrum anthropi YZ-1 by using a Utube microbial fuel cell. Appl. Environ. Microbiol. 2008, 74, 31303137.

(50) Biffinger, J.; Ribbens, M.; Ringeisen, B.; Pietron, J.; Finkel, S.; Nealson, K. Characterization of electrochemically active bacteria utilizing a high-throughput voltage-based screening assay. Biotechnol. Bioeng. 2009, 102, 436-444.

(51) Yan, W.; Sun, F.; Liu, J.; Zhou, Y. Enhanced anaerobic phenol degradation by conductive materials via EPS and microbial community alteration. Chem. Eng. J. 2018, 352, 1-9.

(52) van der Zee, F. P.; Bisschops, I. A. E.; Lettinga, G.; Field, J. A. Activated carbon as an electron acceptor and redox mediator during the anaerobic biotransformation of azo dyes. Environ. Sci. Technol. 2003, 37, 402-408.

(53) Takaya, C. A.; Fletcher, L. A.; Singh, S.; Anyikude, K. U.; Ross, A. B. Phosphate and ammonium sorption capacity of biochar and hydrochar from different wastes. Chemosphere 2016, 145, 518-527.

(54) Xue, Y.; Gao, B.; Yao, Y.; Inyang, M.; Zhang, M.; Zimmerman, A. R.; Ro, K. S. Hydrogen peroxide modification enhances the ability of biochar (hydrochar) produced from hydrothermal carbonization of peanut hull to remove aqueous heavy metals: Batch and column tests. Chem. Eng. J. 2012, 200-202, 673-680. 